\title{
Intravenous Drug Use Rates and Results of Direct-acting Antiviral Treatment in Prisoner Patients
}

\author{
Mahkum Hastalarda İntravenöz İlaç Kullanım Oranları ve Direkt Etkili Antiviral Tedavi \\ Sonuçları
}

\author{
๑ Mehmet Çabalak, ๑ Tayibe Bal \\ Hatay Mustafa Kemal University Faculty of Medicine, Department of Infectious Disease and Clinical Microbiology, Hatay, Turkey
}

\begin{abstract}
Objectives: Intravenous drug use (IVDU) is more common in prisoner patients, and this is a global problem. Hepatitis $\mathrm{C}$ virus $(\mathrm{HCV})$ infection is higher in prisoners than general population. In our study, we aimed to examine the IVDU rates and direct-acting antiviral (DAA) treatment results of the prisoners who applied to Hatay Mustafa Kemal University Clinic of Infectious Diseases.

Materials and Methods: In our study, IVDU rates and HCV treatment results of 85 prisoners who applied to Hatay Mustafa Kemal University Faculty of Medicine Clinic of Infectious Diseases between January 2017 and December 2019 were retrospectively analyzed. Treatment results were evaluated by performing modified intention to tract (mlTT) and per protocol (PP) efficacy analysis, respectively.

Results: The rate of IVDU was $37.7 \%$ in prisoners who were positive for HCV. Although sustained virological response (SVR) rate was $100 \%$ in PP analysis, SVR rate was determined as $80.5 \%$ in $\mathrm{mITT}$ analysis. Viral genotype 3 (41.6\%) and genotype 4 (39\%) were the most common.

Conclusion: However, data on HCV screening and treatment in prisons in Turkey is inadequate or too low. We think that with the use of DAAs, patients' compliance to treatment will increase, it is an important step for HCV eradication and multicenter studies should be conducted.

Keywords: Chronic hepatitis C, prisoners, direct acting antiviral, IV drug user
\end{abstract}

\section{ÖZ}

Amaç: Mahkum hastalarda intravenöz ilaç kullanımı (IVDU) sıklığı ve hepatit $\mathrm{C}$ virüs (HCV) enfeksiyonu prevelansı küresel olarak genel popülasyona göre daha yüksektir. Bu çalışmada Hatay Mustafa Kemal Üniversitesi Enfeksiyon Hastalıkları Kliniği'ne başvurup sağlık hizmeti alan mahkum hastalardaki IVDU oranlarının ve direkt etkili antiviral (DEA) tedavi sonuçlarının incelenmesi amaçlandı.

Gereç ve Yöntemler: Çalışmamızda Ocak 2017- Aralık 2019 yılları arasında Hatay Mustafa Kemal Üniversitesi Tıp Fakültesi Hastanesi Enfeksiyon Hastalıkları Kliniği'ne başvurup sağlık hizmeti alan toplam 85 mahkum hastanın IVDU oranları ve DEA tedavi sonuçları retrospektif olarak incelendi. Sirasıyla modifiye intention to tract ( $\mathrm{mlTT}$ ) ve per protocol (PP) ile etkinlik analizi yapılarak tedavi sonuçları değerlendirildi.

Bulgular: HCV pozitif mahkum hastalarda intravenöz ilaç kullanım oranı \%37,7 idi. PP analizinde kalıcı virolojik yanıt (KVY) \%100 iken mITT analizinde bu oran $\% 80,5$ olarak saptandı. En sık viral genotip $3(\% 41,6)$ ve genotip $4(\% 39,0)$ saptandı.

Sonuç: Cezaevlerinde HCV taranması ve tedavisi açısından Türkiye'de yeterli veri yok veya çok azdır. DEA'ların kullanılması ile hastaların tedaviye uyumunun artacağını, HCV eradikasyonu için önemli bir adım olduğunu ve çok merkezli çalışmalar yapılması gerektiğini düşünmekteyiz.

Anahtar Kelimeler: Kronik hepatit C, mahkum, direkt etkili antiviral, IV ilaç kullanımı

Çabalak M, Bal T. Intravenous Drug Use Rates and Results of Direct-acting Antiviral Treatment in Prisoner Patients. Viral Hepat J. 2020;26:61-64. 


\section{Introduction}

Hepatitis C virus (HCV) is a major global epidemic, and estimated 71 million people worldwide are chronically infected. Approximately 399,000 people die annually due to HCV-related liver failure and cancer in the world $(1,2)$. In the developed countries, intravenous drug use (IVDU) is the main transmission route of $\mathrm{HCV}$ (2). In the literature, unsafe IVDU, sharing of drug paraphernalia, toothbrushes and shavers, tatooing have been identified as a risk factor for HCV infection transmission in prisoners $(3,4,5,6)$. The prevalence of $\mathrm{HCV}$ in prisoners worldwide is up to $26 \%$, and the incidence in prisoners who using intravenous drugs is up to $64 \%$ (3). Due to the physical conditions and psychological characteristics of prisoners, it is difficult for them to access and benefit from health services $(7,8)$. Prisoners may have better access to health care and lower mortality rates in prisons than when they return to society $(7,9)$. HCV treatment can be performed similar or better than the normal population In prisoners $(10,11)$. All prisoners in prisons should be tested for HCV infection (12). HCV is now a preventable and treatable infection, but difficulties remain in reaching infected people $(9,13)$. Prisons can provide a good opportunity to overcome these difficulties. Prison-based screening and treatment should be essential. However, data on HCV screening and treatment in prisons in Turkey is inadequate or too low. In our study, We aimed to discuss the treatment results and IVDU rates of prisoners who were followed up in our clinic due to $\mathrm{HCV}$, by comparing them with other literature data in our country and in the world.

\section{Materials and Methods}

This retrospective, observational, single-center study was performed in prisoners who were followed up by Hatay Mustafa Kemal University Faculty of Medicine Hospital, Clinic of Infectious Diseases. Patients' ages, genders, demographic data, previous treatment experience, drug use, liver biopsy if available, viral load (HCV-RNA levels at $4^{\text {th }}$ week of treatment and after the traetment, $12^{\text {th }}$ and/or $24^{\text {th }}$ week post-treatment) and viral genotype data were obtained from the hospital automation system and patient files retrospectively. Patients younger than 18 years old, who were coinfected with HBV and human immunodeficiency virus were not included in the study. The cases were treated with one of the direct-acting antiviral (DAA) drugs. The drugs used in the treatment are as follows; sofosbuvir \pm ribavirin (SOF \pm RBV), ombitasvir + paritaprevir/ritonavir (OBV + PTV/r) \pm RBV, PrOD [(OBV + PTV/r) \pm dasabuvir (DSV)] \pm RBV, glekapravir + pibrentasvir and ledipasvir + SOF RBV dose was determined according to the patient's weight. DAA drug selection and treatment decisions were made according to the Health Application Communique of the Turkish Social security institution guideline and the decision of physician responsible for treatment (14). HCV genotype and plasma HCVRNA levels were determined by a real-time PCR assay, using either the COBAS AmpliPrep/COBAS Taqman (Roche Molecular Systems Inc., Pleasanton, CA, USA) or the Bosphore HCV Quantification Kit V2 (Anatolia Geneworks, Turkey) with a detection limit of $15 \mathrm{IU} / \mathrm{mL}$ and $25 \mathrm{IU} / \mathrm{mL}$, respectively.

The primary outcome was the proportion of patients achieving a sustained virological response (SVR), which define as an undetectable $\mathrm{HCV}$ viral load at 12 weeks after completion of therapy. Effectiveness assessments other than SVR12 included: early virological response (EVR) (undetectable serum HCV-RNA at 4 weeks of therapy), virologic breakthrough (detectable HCVRNA during treatment when previously undetectable) and relapse (detectable HCV-RNA after treatment when previously undetectable at the end of therapy.

The study was carried out with the approval of Hatay Mustafa Kemal University Faculty of Medicine Retrospective Ethics Committee (approval number: 10, date: 13.02.2020). Due to the retrospective design of the study informed consent was not obtained.

\section{Statistical Analysis}

Treatment efficacy analyzes were performed with both modified intention to tract ( $\mathrm{mlTT}$ ) and per protocol (PP). PP analysis includes the level of HCV-RNA both post-treatment and after completing 12 weeks of follow-up. For mITT analysis, in addition to the HCVRNA value measured prior to treatment, patients had to have a measured HCV-RNA value at least in the first month of treatment and all patients whose SVR12 was unknown were accepted as unresponsed when conducting $\mathrm{mITT}$ analysis. For statistical analysis, IBM SPSS version 23.0 statistical package program (SPSS Inc, Chicago, IL, USA) was used. The compatibility of variables to normal distribution was tested using the Kolmogrov-Smirnov test and histogram. Median and interquartile intervals were used for variables that do not fit the normal distribution.

\section{Results}

In our study, a total of 85 prisoner patients used DAA treatment between 2017-2019. Six of these patients were excluded from the study because they had never used the treatment and did not come to follow-up, and two patients were excluded from the study because their medication was just started. All of the patients were male. The rate of IVDU in HCV positive prisoners was $37.7 \%$ (29/77). To evaluate the effectiveness, $\mathrm{mlTT}$ in 77 cases and PP analysis in 60 cases were used. While SVR was 100\% in PP analysis, this rate was $80.5 \%$ in $\mathrm{mlTT}$ analysis.

In our study, the average age of 77 patients who evaluated by $\mathrm{mITT}$ efficacy analysis was 30 [interquartile range (IQR): 25-33.5]. Eighteen cases (23.4\%) in 2017, 21 cases (27.3\%) in 2018, 38 cases $(49.4 \%)$ in 2019 were included in our study. The number of prisoner patients whose treatment is started by years was shown in Figure 1.

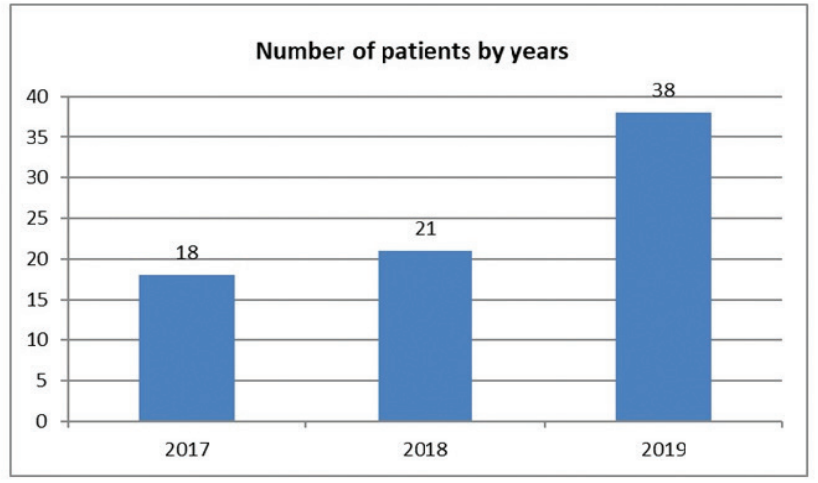

Figure 1. Number of patients by years 
The genotype distribution of the patients is as follows; genotype 1a: 5 cases (13\%), genotype $1 \mathrm{~b}$ : 2 cases $(2.6 \%)$, genotype 2 : 7 cases $(9.1 \%)$, genotype 3: 32 cases $(41.6 \%)$, genotype 4: 30 cases $(39.0 \%)$, mixed genotype: 1 case $(1.3 \%)$. Viral genotype distribution in prisoner patients was shown in Figure 2. The treatments that patients receive are as follows; 22 patients SOF \pm RBV (28.6\%), 28 patients OBV + PTV/r (36.4\%), 7 patients PrOD (OBV + PTV/r + DSV) \pm RBV (9.1\%), 19 patients glecapravir + pibrentasvir (24.7\%), 1 patient SOF + LED (1.3\%). RBV (71.4\%) was used in 55 cases. No virological exacerbation and relapse were detected during treatment. EVR was obtained in 72 cases (93.5\%). Only one case was treatment experienced.

Only 17 of 29 patients with a history of IVDU was achieved SVR. The rate of SVR in patients with IVDU was 17/29 (58.6\%). There was a significant difference between with and without IVDU in terms of SVR ( $p=0.000)$. In our study, headache, bloating, weight loss and insomnia were observed as side effects in patients who were followed-up regularly. Especially in three patients using $\mathrm{OBV}+\mathrm{PTV} / \mathrm{r}+\mathrm{DSV} \pm \mathrm{RBV}$, minimal aspartate aminotransferase/ alanine aminotransferase elevation and isolated bilirubin elevation were detected, but no treatment was discontinued due to serious adverse effects. In our study, liver biopsy was performed in six patients and no cirrhotic patient was detected.

\section{Discussion}

In studies evaluating the response of peg-interferon (IFN) + RBV therapy, SVR at the end of treatment was determined between $28 \%$ and $69 \%$ in prisoner patients with hepatitis C $(1,15,16,17,18,19,20,21,22,23)$. In the study conducted by Ozger et al. (24), only 33 of the 99 patients who started Peg-IFN + RBV treatment had SVR at the $6^{\text {th }}$ month after treatment. DAAs' used in $\mathrm{HCV}$ treatment are more effective, reliable and tolerable drugs compared to interferon-based regimens (25). In our study, SVR12 was obtained in 60 of 77 patients whose treatment was started. In patients who completed the treatment, SVR12 was $100 \%$. Although they received DAA treatment, it was thought-provoking that SVR12 was not examined in 17 patients. Second-generation DAAs are a great improvement in the completion of the treatment and follow-up of prisoners, as their short course of treatment is reliable and tolerable (26). However, in our study, the most important reason for not continuing to treatment and follow-up was determined as the fact that prisoners did not come to follow-



Figure 2. Viral genotype distribution in prisoner patients HCV: Hepatitis C virüs, GT: Genotype up after release. According to the study of Larney et al. (3), the prevalence of anti $\mathrm{HCV}$ in prisoners is $26 \%$, while it can be up to $64 \%$ in IV drug addicted prisoners. In the same study, while anti $\mathrm{HCV}$ was $1.4 \%$ in the general population, anti HCV was found to be $16.4 \%$ in IV drug addicts (3). In our study, the rate of IVDU in prisoners with HCV infection was 37.6\% (29/77). We think that this may be due to the low number of patients and geographical region differences. In the study conducted by Zampino et al. (25), The prevalence of anti HCV in convicted patients reported between 3\% and 38\% according to geographic region, IV drug use, age, duration of imprisonment, and prisoners' history. The most common genotypes in studies are genotype 1 and $3(25,27)$. In Turkey, there are very few studies on prisoner patients. In the study conducted by Keten et al. (28), the most common genotype among prisoners in Turkey is genotype $3(68.1 \%)$. In the study of Ozger et al. (24), Genotype 3a is 66.7\% (66/99). Unlike the literature, the remarkable result in our study was that genotype 4 was found to be $39 \%$ (30/77). However, we found the most common genotype is genotype 3 , as $41.6 \%$ (32/77). We think that this difference may be due to geographical region difference. Only 17 of 29 patients with a history of IVDU reached SVR-12. SVR-12 was not known in 12 cases. The rate of SVR-12 in patients with a history of IVDU was 17/29 (58.6\%). When patients with and without IVDU history were compared in terms of SVR, there was a significant difference. The antiviral treatment response in prisoners is similar to the general population $(10,11)$. Unfortunately, treatment compliance is low in prisoners because treatment follow-up and management are difficult. In our study, it was found that treatment compliance was low, especially in patients with a history of IVDU. The most important reason for not continuing to treatment and follow-up was determined as the fact that prisoners did not come to follow-up after release. Side effects are an important factor affecting treatment results and continuation of the treatment, but in our study, no patient was discontinued their drugs due to drugrelated side effects.

\section{Study Limitations}

The limitation of our study is that it is a retrospective study, the data is regional and the number of cases is low.

\section{Conclusion}

We think that prisoners provide a good opportunity to increase the diagnosis and treatment of HCV infection. We think that the compliance of patients to treatment will increase with the use of second-generation DAA drugs and it is an important step for HCV eradication and we suggest that multicenter studies should be conducted in our country.

\section{Ethics}

Ethics committee approval: The study was carried out with the approval of Hatay Mustafa Kemal University Faculty of Medicine Retrospective Ethics Committee (approval number: 10, date: 13.02.2020).

Informed Consent: Due to the retrospective design of the study informed consent was not obtained.

Peer-review: Externally peer-reviewed. 


\section{Authorship Contributions}

Concept: M.Ç., T.B., Design: M.Ç., T.B., Data Collection or Processing: M.Ç., Analysis or Interpretation: T.B., Literature Search: M.Ç., Writing: M.Ç.

Conflict of Interest: The authors declare no conflict of interest.

Financial Disclosure: The authors declare that this study has not received any financial support.

\section{References}

1. WHO 2017. Global Hepatitis Report 2017, World Health Organization. Geneva; 2017

2. Nelson PK, Mathers BM, Cowie B, Hagan $H$, Des Jarlais $D$, Horyniak D, Degenhardt L. Global epidemiology of hepatitis B and hepatitis $C$ in people who inject drugs: results of systematic reviews. Lancet. 2011;378:571-583.

3. Larney S, Kopinski H, Beckwith CG, Zaller ND, Des JD, Hagan $H$, Rich JD, van den Bergh BJ, Degenhardt L. Incidence and prevalence of hepatitis $C$ in prisons and other closed settings: results of a systematic review and meta-analysis. Hepatology. 2013;58:1215-1224

4. Cunningham EB, Hajarizadeh $B$, Bretana NA, Amin J, BetzStablein B, Dore GJ, Luciani F, Teutsch S, Dolan K, Lloyd AR, Grebely J, HITS-p investigators. Ongoing incident hepatitis $C$ virus infection among people with a historyof injecting drug use in an Australian prison setting, 2005-2014: the HITS-pstudy. J Viral Hepat. 2017;24:733-741.

5. Drummond A, Codd M, Donnelly N, McCausland D, Mehegan J, Daly L, Kelleher CC. Study on the prevalence of drug use, including intravenous drug use, and blood-borne viruses among the Irish prisoner population. Dublin: BMJ Publishing Group Ltd. 2014.

6. Vescio MF, Longo B, Babudieri S, Starnini G, Carbonara S, Rezza G, Monarca R. Correlates of hepatitis C virus seropositivity in prison inmates: a meta-analysis. J Epidemiol Community Health. 2008;62:305-313.

7. Fazel S, Baillargeon J. The health of prisoners. Lancet. 2011;377:956-965.

8. Fazel S, Bains P, Doll H. Substance abuse and dependence in prisoners: a systematic review. Addiction. 2006;101:181-191.

9. Martin NK, Vickerman P, Dore GJ, Hickman M. The hepatitis C virus epidemics in key populations (including people who inject drugs, prisoners and MSM): the use of direct-acting antivirals as treatment for prevention. Curr Opin HIV AIDS. 2015;10:374-380.

10. Aspinall EJ, Mitchell W, Schofield J, Cairns A, Lamond S, Bramley P, Peters SE, Valerio H, Tomnay J, Goldberg DJ, Mills PR, Barclay ST, Fraser A, Dillon JF, Martin NK, Hickman M, Hutchinson SJ. A matched comparison study of hepatitis $\mathrm{C}$ treatment outcomes in the prison and community setting, and an analysis of the impact of prison release or transfer during therapy. J Viral Hepat. 2016;23:1009-1016

11. Maru DS, Bruce RD, Basu S, Altice FL. Clinical outcomes of hepatitis $\mathrm{C}$ treatment in a prison setting: feasibility and effectiveness for challenging treatment populations. Clin Infect Dis. 2008;47:952-961

12. ECDC; EMCDD. Systematic review on active case finding of communicable diseases in prison settings. Stockholm: 2017.
13. Hajarizadeh B, Grebely J, Matthews GV, Martinello M, Dore GJ. The path towards hepatitis $C$ elimination in Australia following universal access to interferon-free treatments. J Hepatol. 2017;66:S291-292.

14. Health Application Communique of the Turkish Social Security. Available from: http://www.sgk.gov.tr.

15. Lloyd AR, Clegg J, Lange J, Stevenson A, Post JJ, Lloyd D, Rudge G, Boonwaat L, Forrest G, Douglas J, Monkley D. Safety and effectiveness of a nurse-led outreach program for assessment and treatment of chronic hepatitis $\mathrm{C}$ in the custodial setting. Clin Infect Dis. 2013;56:1078-1084.

16. El-Kamary SS, Jhaveri R, Shardell MD. All-cause, liver-related, and non-liver-related mortality among HCV-infected individuals in the general US population. Clin Infect Dis. 2011;53:150-157.

17. Boonwaat L, Haber PS, Levy MH, Lloyd AR. Establishment of a successful assessment and treatment service for Australian prison inmates with chronic hepatitis C. Med J Aust. 2010;192:496-500.

18. Farley J, Vasdev S, Fischer B, Haydon E, Rehm J, Farley TA. Feasibility and outcome of HCV treatment in a Canadian federal prison population. Am J Public Health. 2005;95:1737-1739.

19. Farley JD, Wong VK, Chung HV, Lim E, Walters G, FarleyTA, Yoshida EM. Treatment of chronic hepatitis $\mathrm{C}$ in Canadian prison inmates. Can J Gastroenterol. 2005;19:153-156.

20. Sterling RK, Hofmann CM, Luketic VA, Sanyal AJ, Contos MJ, Mills AS, Shiffman ML. Treatment of chronic hepatitis $C$ virus in the virginia department of corrections: can compliance overcome racial differences to response? Am J Gastroenterol. 2004;99:866872.

21. Allen SA, Spaulding AC, Osei AM, Taylor LE, Cabral AM, Rich JD. Treatment of chronic hepatitis $C$ in a state correctional facility. Ann Intern Med. 2003;138:187-190.

22. Strock P, Mossong J, Hawotte K, Arendt V. Access to treatment of hepatitis C in prison inmates. Dig Dis Sci. 2009;54:1325-1330.

23. Martin CK, Hostetter JE, Hagan JJ. New opportunities for the management and therapy of hepatitis $\mathrm{C}$ in correctional settings. Am J Public Health. 2010;100:13-17.

24. Ozger HS, Karaşahin O, Toy MA, Yılmaz SI, Hızel K. Hepatitis C Prevalence and Responses to Pegylatedlnterferon + Ribavirin Treatment Among Prisoners.Viral Hepatitis Journal. 2017;23:7175.

25. Zampino R, Coppola N, Sagnelli C, Di CG, Sagnelli E. Hepatitis $C$ virus infection and prisoners: epidemiology, outcome and treatment. World J Hepatol. 2015:7:2323-2330.

26. Liu S, Watcha D, Holodniy M, Goldhaber-Fiebert JD. Sofosbuvirbased treatment regimens for chronic, genotype 1 hepatitis $\mathrm{C}$ virus infection in U.S. incarcerated populations: a costeffectiveness analysis. Ann Intern Med. 2014;161:546-553.

27. Mahowald MK, Larney S, Zaller ND, Scharff N, Taylor LE, Beckwith CG, Noska A, Rich JD, Flanigan TP. Characterizing the Burden of Hepatitis C Infection Among Entrants to Pennsylvania State Prisons, 2004 to 2012. J Correct Health Care. 2016;22:41-45.

28. Keten D, Ova ME, Keten HS, Keten A, Gulderen E, Tumer $\mathrm{S}$, Caliskan A, Kulotu S. The Prevalence of Hepatitis B and C Among Prisoners in Kahramanmaras, Turkey. Jundishapur J Microbiol. 2016;9:e31598. 